\title{
Resistance and relief: The wit and woes of early twentieth century folk and country music
}

IAIN ELLIS

\section{Abstract}

Folk and country music were rural-based music styles that developed during the pre-rock decades of the early twentieth century. Largely performed by working-class practitioners for working-class audiences, these genres captured the hardships of poor constituencies through markedly different means of humorous expression. Whereas folk employed an often strident satire in resisting perceived oppressors, country looked inwards, using selfdeprecating and personalized humor as a shield and relief against outside forces. Narrative tall-tales and regional vernacular were ubiquitous features of folk and country humor, and both crafted struggling characters to serve as illustrative metaphors for broader class concerns. In surveying these music forms in their infancy - as well as their key players - we are connected to the roots of American humor, as well as subsequent developments in rock \& roll rebellion.

Keywords: Country; humor; resistance; relief; working-class.

Pre-rock popular music in the U.S. was a splintered affair, where limited communications technology kept musical forms and styles within narrow parochial confines. Mostly performed by working-class artists for working-class audiences, pre-rock genres spoke in the argots of their respective regions and demographic audiences. Consequently, a vast panorama of styles developed across the nation in relative isolation from one another. During the early decades of the twentieth century, the burgeoning forms of blues, jazz, and swing developed within predominantly 
African-American communities, while folk and country became the representative styles of white rural America. Sometimes these genres intersected, but for the most part they operated independently. What united them were less musical commonalities than cultural ones. For both black and white working-class communities, personal and collective hardships were omnipresent realities that they could not not know, the Great Depression years (as well as the years prior and after) defining a sweeping class condition of scarcity and struggle. The musical representatives of these sub-cultures responded to their woes in myriad fashions, though all drew from a survivalist humor of some kind as a coping mechanism.

Whereas swing performers often escaped from the realities of racism and poverty by flaunting fantasies of grandeur with exuberant humor, jazz and blues acts tempered such positive vibes with double-speak wordplay and thinly-veiled social critiques. Within white rural communities, folk singers tended to address their hand-to-mouth hardships with "ain'tgonna-take-it-anymore" resistant protests aimed squarely at the "oppressive" institutions and systemic forces they deemed responsible. Conversely, country \& western musicians assumed a less polemical approach to their woes, adopting a more personal and defensive stance against outside forces, as opposed to folk's aggressive, attacking one. Despite their disparate responses to common social circumstances, each genre's key players wielded tools of humor intended to serve as relief for themselves and their communities. Paraphrasing Thomas Hobbes, John Morreall captured the resistant nature of such "relief humor" thusly: "To laugh in breaking free of constraint can also be to laugh in scorn at those who have been constraining one" (1983: 20).

Unlike folk counter-parts like Joe Hill and Woody Guthrie, country humorists like Uncle Dave Macon and Jimmie Rodgers expressed an unformed, pre-political consciousness, one often contradictory in nature. And where folk humorists were pumping fists and rousing workingclass spirits with their satirical anthems of programmatic resistance, the country wits told self-deprecating narrative tales of fatalistic resignation - often with grins on their faces! Unlike the spit and vinegar of folk's assertive satire, country \& western humor was "loser" humor, the humble reflections of the victim. Within both, though, it was the individual who served as the metaphorical representative of the socially struggling collective, the personal "I" thereby signifying the political "We." 


\section{Folk resistance}

The folk music of America is a by-product of the nation's poor European settlers and the music they brought with them. That such music has stood the test of time speaks to the stability and conservative character of the rural outposts where it gestated and mutated through generations of global immigrant interactions. Folk's longevity is also a reflection of it being a storytelling vehicle, a source of oral history in narrative form; it is literary at its core. Its stories date back to, and beyond, Elizabethan ballads, though in their particular American context they draw much from the frontier tall-tales of the prior two centuries and from the Southwestern picaresque humor of the likes of Mark Twain and George Washington Harris. In their writings we are introduced to the innocent rogues, ironic truth-tellers, and tricksters that developed as central comedic characters in the folk music of the late nineteenth and early twentieth centuries.

Woody Guthrie's mythologized survivalists and diamonds-in-the-rough are the prototypical folk characters that have lived many subsequent lives in folk music revivals from the 1950s to the present, particularly in the work of such seminal rock literati as Pete Seeger, Bob Dylan, and Bruce Springsteen. This folk tradition has been a forceful and influential one, with truth-stretching tales of romantic transcendence, and dialect-driven anecdotes of the working-class everyman who chastens authority through guile and wit. Such narrative humor continues to regenerate across generations, inspiring young people during their restless teenage years, speaking to their rebellious instincts, and engaging them with their nation's "dream" ideology.

The history of folk music - both prior to and throughout rock's heritage - is a history of struggle over the concept and reality of the American Dream, how its promises have often gone unfulfilled and its social justice principles found wanting. Its point-of-view is that of the underdog, whether in its most traditional form from a working-class perspective, or more recently from black, gay, female, or other perspectives that represent identity positions of subjugation within the broader society. To a youth untamed by adult compromise, his/her antenna fixed to receive and respond to the hypocrisy of the parent generation, the spirit of folk music can be the very lifeblood of youth rebellion. That its lyrical style is often mocking and satirical of the purveyors of injustice adds motivating fuel to that rebellion, enabling anger to merge with an 
empowering scorn. The effects of folk satire are particularly inspirational in the group context. From Joe Hill's mocking fables of predatory preachers and traitorous scabs, to Woody Guthrie's tall-tales of vagabonds and vigilante heroes, to Bruce Springsteen's bleakly ironic mantra of being "born in the U.S.A.," folk music has been what the keyword suggests: the music of the people. Whether performed on picket lines, on the radio, or to a stadium full of fans, the uniting effect of folk songs has concretized and sometimes created communities, protest power blocks relieved by the empathy of the messages and uplifted by the hope of change that they offer.

As a genre that prides itself on realistic candor, not surprisingly, many folk songs speak to living conditions, social relations, and aspirations - in short, politics. This political content has used the micro to reveal macro issues, intimate stories of individuals functioning as metaphorical emblems for the larger conditions of the people. Thus, many folk songs present serious messages, though one should not underestimate the powerful role humor has always played as both a defensive relief mechanism and as a weapon of satirical attack in their articulation. Nowhere is the political humor of folk more manifest than in the formative writing and activism of Joe Hill.

\section{Joe Hill}

The grandfather of subversive folk humor in America is Joe Hill, a man, like a character in many a folk song, whose life has posthumously taken on mythic proportions within labor and folk music circles. A Swedish immigrant, Hill was an itinerant laborer who became a principle organizer of the Industrial Workers of the World, or Wobblies, in the pre-teen years of the twentieth century. As an activist, propagandist, and songwriter for the I.W.W., he incited and inspired the largely disorganized workers of America with inspirational and satirical folk songs that were performed in the workplace, on picket lines, in jails, and anywhere else they might serve their politically utilitarian purpose. Furthermore, many of his song lyrics were collected, in 1909, into The Little Red Songbook, a compact collection that could fit into your shirt pocket. Well-circulated across the land, the songbook was given out to all new I.W.W. members, making the Wobblies what Pete Seeger has called "the singingest union America ever had" (Seeger 1972: 74). 
Strong believers in the power of song to physically unite and emotionally excite, the I.W.W. used Hill's and others' songs as a central feature of their agit-prop practices. As might be expected, Hill's lyrical mockery of the bourgeoisie - for its worker exploitation, base values, and hypocrisy - was not exactly well-received by the powers-that-be. Under circumstances still shrouded in mystery, Hill was arrested in 1915 on a (supposedly) trumped-up murder-robbery charge, and was later executed by a firing squad. Though physically removed as an irritant to the guardians of the capitalist hegemony, Hill soon became a martyr to the struggling labor movement, inspiring generations of future workers and folk singers.

Joe Hill contributed about thirty songs to The Little Red Songbook, each following the same strategically formulaic approach. Though the lyrics were all original creations, Hill always set them to the familiar pop songs of the day, creating a milieu of accessibility and audience engagement, as well as suggesting a parody of the sentimental and escapist themes of the original songs. Lyrically, the songs tackled many of the topics - and approaches to those topics - that we have since become familiar with through the folk genre. A celebratory, rousing humor was employed in songs aimed to rally and inspire the workers, while a caustic, satirical style was used in exposing the violence and exploitation practiced by various proponents and pawns of the ruling order (bosses, scabs, cops, army, and government) against the workers.

Hill recognized that power relations were sustained by cultural forces, too, ones that served to solidify institutional might and to divide and distract the working-classes. A prime enemy in this regard was organized religion, which features as the satirical butt of many of Hill's secular sermons. Borrowing the tune of the Salvation Army hymn, "In The Sweet Bye and Bye," Hill inserted his own lyrics and title, writing what became one of his more hailed songs, "The Preacher and The Slave" (1992). Here, he mocked the moral inconsistencies of religious leaders, as well as introduced the world to the expression "pie in the sky" (1992). The first verse reads, "Long-haired preachers come out every night / Try to tell you what's wrong and what's right / But when asked how 'bout something to eat / They will answer with voices so sweet" (Hill 1992). Alluding to the original hymn, the chorus then goes: "You will eat, bye and bye / In that glorious land above the sky / Work and pray, live on hay / You'll get pie in the sky when you die" (Hill 1992). Such messagelyrics retain their resonance today in our age of televangelists and other 
theocratic advocates of passive fatalism. Hill's satirical barbs turn to revenge fantasies in "Nearer My Job To Thee," the title of which, again, playfully puns on the sacred (1992). Here, Hill targets bosses whose concerns and considerations never extend beyond their own bottom line; his threat embodies both humor and anger in singing, "When that shark I see / You'll bet your boots that he / Nearer his god shall be / Leave that to me" (Hill 1992).

The legacy of Joe Hill runs long and deep. In the next decades he would inspire such kindred spirits as filmmaker Charlie Chaplin, writers Upton Sinclair and Carl Sandburg, and folk-singing disciple Woody Guthrie. Later, in the 1950s and '60s, his shadow lingered over the new breed of young folk singers, led by Pete Seeger, and later followed by Joan Baez, Bob Dylan, and Phil Ochs; the latter even paid tribute with his song "Joe Hill." Since the 1970s, artists like Bruce Springsteen, Billy Bragg, and Steve Earle have continued the tradition started by Joe Hill, one that aims to describe, speak for, and inspire — via humor - the folk cultures of America's oft-ignored working-class.

\section{Woody Guthrie}

Proud owner of a Little Red Songbook, Woody Guthrie popularized Joe Hill's folk styles beyond the picket lines and cotton fields. Born in the small town of Okemah, Oklahoma, in 1912, Guthrie strapped his guitar to his back and set about a life of rambling at the age of fifteen. What he found on his travels around the rural South and West during the 1930s was a country in crisis. Poverty, homelessness, and unemployment were battering the spirits of the folks of the rural heartland, and Guthrie assumed as his mission the task of documenting and commenting upon their plight. By the time he reached New York in the early 1940s, Guthrie had become a legendary figure, revered by workers and sympathetic intellectuals alike. Seen as a cross between Walt Whitman and Huck Finn, Guthrie grew to be regarded as America's most revered folk singer, earning himself such monikers as "Bard of the Okies" and "Shakespeare in Overalls" (Malone 2002: 130).

Amongst the various lumpen proletariat characters Guthrie was inspired by for his humorous narratives was the gangster. Neither criminals nor public enemies in his songs, Guthrie mythologized the likes of Pretty Boy Floyd as populist heroes. Floyd was a Robin Hood figure to Guthrie 
in much the same way that John Gotti was revered by many of the working-class residents of his New York locality. Implicitly chastising the real enemies of the working man-exploitative landlords and bosses - Guthrie wryly commented in his song, "Pretty Boy Floyd" (1999), "You won't never see an outlaw / Drive a family from their home" (Guthrie 1999). His tall-tales of romantic gangsters who steal from the rich to help the poor are further romanticized in other songs like "Jesse James" and "Belle Star." To Woody Guthrie, the gangster was just one more underdog made scapegoat by an oppressive bourgeois class that itself remained untouched by its own sanctioned criminality.

Another group Guthrie regarded as unfairly under siege was the hobos. As a fellow traveler, he could appreciate the hardships of the hobo, who was often doubly victimized at the hands of the police force and hired vigilantes. Their crime, according to Guthrie? Traveling in order to try and find work. In "Hobo Bill's Last Ride" and "Hobo's Meditation," he called attention to this subaltern breed spawned as a by-product of the Great Depression. His country contemporary, Jimmie Rodgers, also wrote tall-tales of the free-wheeling hobo life, though his perspective was notably different than Guthrie's. A romanticist of the traveling man, Rodgers was quick to celebrate the fated migration of the dust bowl farmers of the heartland as they sought "milk and honey" in the promise of California. More rooted in the realist traditions of folk than the escapist fantasies of Rodgers' country dreamscapes, Guthrie scolded his fellow singer in the scornful parody song, "Dust Pneumonia Blues" (2000). Following the country-blues formula of the typical Jimmie Rodgers song, Guthrie wittily disparages the false hopes Rodgers was feeding to the desperate workers of the heartland states. In case listeners did not pick up on the parody of the musical form, Guthrie tells us that "There ought to be some yodeling in this song," calling attention to Rodgers' patented vocal technique (2000). Then, Guthrie follows this line with "But I can't yodel for the rattlin' in my lung," penetrating Rodgers' pipe-dreams with harsh reality (Guthrie 2000). Such "answer" songs as "Dust Pneumonia Blues" remind us of the aesthetic in-fighting common within jazz circles of the time, establishing Guthrie within a tradition of in-house signifying humor that has remained throughout subsequent rock (and particularly rap) history.

As with Joe Hill, the legacy of Woody Guthrie is incalculable. That the young Bob Dylan would make a pilgrimage from Minnesota to Guthrie's New York death-bed in 1960 speaks to the intensity of his influence. 
Employing what Ray Pratt called "a critical eye combined with a wry wit and humor," Guthrie left behind a catalogue of over one thousand original songs, many of which were dedicated to relieving suffering through humor, and inspiring the disenfranchised through his concerns for increasingly fractured rural communities (1990: 115). Such purposes and considerations would be the cornerstone principles of the many future rockers who would feel the touch of his heart, mind, and humor.

\section{Country \& western relief}

For all the similarities between the folk and country music cultures, it is the differences that reflect their distinct senses of humor and how they relate internally and externally to working-class identity. Unlike many of the folk artists of the twentieth century's early decades, the country acts rarely had political associations, political content, or a discernible political perspective. Moreover, even when anger or frustration were expressed in relation to an unwelcome social development or political trend, the protest tended to be internalized or obliquely individualized, and any pointed humor tended to be aimed internally with self-deprecation or extra-externally in the forms of fantasy tall-tales, escapist faith, or distorted nostalgia. Such means of expression contrasted starkly with the assertive protests of politicized folk singers, who were never bashful in zeroing in on perceived oppressors and attacking with vitriol and ridicule. Despite often being born and bred in the very same heartland rural cultures, to play folk music or country \& western was apparently to see the world through very different lenses and to respond to it by very different means.

Like the folk style, country \& western music tends to be a strippeddown musical form that relies upon the inflections of the voice that delivers. But whereas a folk singer will often echo the lyrical sentiment through his/her vocal style, a country singer's voice will often run counter to the apparent lyrical message. Within the history of country music, the grain of the voice has spoken volumes, often exuding a complex amalgam of emotions that have a complicated relationship to the words being sung. This has particular implications to the meanings of country music humorists and the messages they are ultimately conveying.

As with the folk music of the early twentieth century, country music developed out of the nation's rural, working-class, immigrant popula- 
tions. Also like folk, country accentuates its lyrical components, the music offering few deviations from the template three-chord structures. Country also shares with folk humor a predilection to Aristotelian "superiority" humor (Morreall 1983: 5). This method ridicules anyone "uppity" and "holds derision concerning affected or pretentious ways" (Malone 2001: 179). Its down-to-earth posture and humble essence are apparent in country artists' identity and identification. Whereas the ostentation of swing led the likes of Basie to show off the tag "Count" and Ellington to claim he was a "Duke" in their own versions of upwardlooking superiority boasts, country \& western singers of the same eraby contrast, but with equally self-conscious (inverted) snobbery - used the singularly syllabic abbreviations of their Christian names: "Bill" not William-Monroe, "Uncle Dave" - not David-Macon, and "Hank" - don't call him "King Hiram" - Williams. No high-falutin monikers here; just the ironic simplicity of rube (not Reuban!) humor.

Country humor, at its most political, invariably implicates the corrupt, the overly-powerful, and the bureaucratic. Unlike with folk, though, this ridicule is rarely explicit, but is usually coded within an individual tale or a homely reference. Rather than preach a social message, the country humorist will spin a yarn, using an individual character as a metaphor for a broader social condition. To be as presumptuous as to make overt political declarations or grandstand would be, as Bill Malone puts it, "getting above your raisin" (Malone 2001). Country humor is humble humor, fatalistic in the face of hardships and victim-oriented in relation to pointof-view. Less call-to-arms assertive and more "batten-down-the-hatches" defensive, country lyrics might slight city-slickers and corrupt government, but it will do so in order to illustrate the effects on the working-class rather than as a call for class solidarity or resistance. The social inequities outlined in country songs are, thus, pre-political in nature, expressing a condition rather than a strategy for addressing that condition.

The subversive element of this pre-political consciousness can often be found in the vocal delivery, which has the capacity to reflect resilience in the face of exploitation and proud defiance in the face of defeat. Songs that could otherwise degenerate into sagas of self-pity are transformed - via the character of the voice - into moving tributes to survival and strength, buffering the forces of privation. Projected through country's characteristically self-effacing wit, relief humor is provided to an audience who recognize the sentiments of an individual narrative by 
virtue of having lived it. Hence, a song like Jimmie Rodgers' "T.B. Blues" (1997) is transformed from a harrowing autobiographical tale into a collective metaphor of resistance and dignity. And when Uncle Dave Macon asserts lyrical perspectives on the automobile and the Scopes trial that one might be inclined to dismiss as backwards and conservative, his humor actually embodies a contradictory consciousness, one that reflects reactionary fatalism, but also a fear of all establishments, governments, and change because harsh experience has shown such anxieties to be justifiable.

The ability of country humorists to laugh at themselves and their culture has been a strain of humor at the heart of the genre historically. Whereas the jazz and swing artists of the day were intent on projecting images that would condemn racial stereotypes and fostering upwardlymobile, go-getter dignity, contemporary white musicians within the country genre employed a humor that was the polar opposite. Indeed, country wits have arguably done more to perpetuate demeaning stereotypes of rural folk than anyone outside of that culture through their practices of "rube" humor. The term itself is a slang abbreviation of Reuben, a common Christian name employed by country culture and beyond as a stereotypical representative of an unsophisticated Southern male. An offspring of the minstrel tradition, "rube" humor uses similar grotesque caricatures and the same forms of sketch comedy (with silly wordplay), novelty songs (often banjo-based jaunty-jigs), and ironic dancing (i.e., deliberately bad). However, rather than satirizing "po" "blacks through whites using blackface (as the minstrels did), "rube" humor ridicules "po"” whites through whites using "rednecks." From Uncle Dave Macon and Minnie Pearl in the 1930s to Gretchen Wilson and Larry the Cable Guy today, country humorists have looked internally and down for their subjects, laughing with exaggeration at their own stereotypical traits. On the surface, it is as though minstrel humor had re-planted itself into the soil of twentieth century white rural culture. To an extent, this parallel makes historical sense, as both share the nineteenth century vaudeville tradition in their foundations; however, the regressive humor "type" has certainly lingered longer within country music than elsewhere.

The stereotypes perpetuated by "rube" humor - cheating, boozing, disheveled losers - project both self-loathing and self-protection through caricatures that are lovingly embraced as both recognizably "us" and a mockery "of us" from an outside "them." By making fun of the "redneck" type, the satirist is giving recognition to the caricature and 
his/her part-ownership of it, whilst also declaring - through laughter and exaggeration - that he/she is outside of that persona. In proud selfdefense, the country humorist is implicitly saying, "I know that you rich city folk see us this way - go ahead." The comic result is a pre-emptive strike against establishment outsiders and a self-affirming dignity in country's working-class solidarity - unpretentious, humble, and strong enough to be able to laugh at itself. Unraveled, the country humorist is subversive at the pre-political level, providing a defensive front by stealing the master's tools, affirming a common humanity, and providing relief in its survivability. Expressed by "outsiders" such humor has no permit, and is merely offensive and prejudicial, a manifestation of the very anti-country elitism that "rube" humor, in country hands, ultimately unveils.

\section{Uncle Dave Macon}

In recognizing the different humor used within the folk and country genres we are offered a window into distinct characters with divergent perceptions of self-identity. One figure who embodied, reflected, and propagated the styles of humor we have seen developed throughout the history of country music is Uncle Dave Macon. He serves as a bridge from nineteenth century rural humor (and culture) to the twentieth century. Born in Warren County, Tennessee, in 1870, David Harrison Macon grew up in his father's town boarding-house, witnessing firsthand the many vaudeville shows that traveled through the South. Until the ripe age of fifty, Macon was a full-time working man, either as a farmer or hauling goods with a mule and cart. Developing his hobbies as a comedian and banjo player on the side, he set to recording in 1924 and two years later was invited to be a cast member of the then-infant Grand Ole Opry. He would remain as one of the Opry's most beloved regulars until his death in 1952. During the years in-between, he developed hundreds of songs that would define his particular brand of working-class country humor.

Accompanied by his band, the Fruit Jar Drinkers (slang for moonshine containers), Macon's music and humor drew from past and present; the good-natured, earthy, vernacular humor was drawn from nineteenth century vaudeville, while the driving banjo-based sound was one that fused minstrel styles with the rural blues with Tin-Pan Alley pop. The nature 
of Macon's humor spanned from the silly to the subtly subversive. The former was evident in his debut 1924 recording, "Chewing Gum," a song that enabled him to exercise his vaudevillian physical humor of facial distortions and child-like playfulness. With his gold tooth shining from his Cheshire cat grin, Macon would sport his patented plug hat on stage, waddling and wiggling in his seat, periodically playing with his chin whiskers or spinning his banjo behind his back between verses. "Old School" country singer, Marty Stuart, once called him "our first rock star," and it was his sheer celebratory force of character that made him an adored "Uncle" wherever he took his act (Macon 2004: 2).

As was common with most folk and country acts of the 1920s and ' 30 s, Uncle Dave Macon wrote about the topics of his place and times. But whereas in the hands of a Woody Guthrie, a song about the Great Depression would likely address the root causes and describe the details of the working man's suffering, Uncle Dave offered a more muted comment and more personalized humor. In his "All In and Down \& Out Blues" Macon brings the light relief of childish wordplay in describing a Depression victim: "It was hippety-hop to the bucket shop / I've lost all my money and now I have flopped" (Macon 2004). In the same song, his reference to the 1929 "crash" captures light-hearted country skepticism rather than folk outrage: "Now this is the truth and it certainly exposes / That Wall Street's proposition is not all roses" (Macon 2004). The humor here is pre-political rather than a-political. It reflects the protective insularity of the country community, one defined by self-reliant individualists who are always suspicious of outsiders, particularly extraneous institutions that might disrupt or harm the conservative stability of rural existence.

Such a sensibility was apparent in many of Macon's topical songs, which ranged from the plight of the farmers in "Farm Relief" to the 1925 Scopes trial in "The Bible's True." In both, the protest (if it qualifies as such) is against change, rather than a reasoned position on the merits or effects of the issues. Thus, Macon's humor, like so much country humor, reflects a contradictory consciousness. Sometimes it is strikingly politically incorrect (e.g., Macon's "Run, Nigger Run"), often-times it is conservative to the detriment of the community's better interests, but it is ultimately a humor born of suspicion and anxiety about the outside forces over which that community has no control. It speaks to a survival instinct rather than a rational one, and places its trust in home, hearth, and heaven, rather than with "meddlin"” outsiders. Uncle Dave's fears 
of change were at times born out of his own personal experiences. It was the development of the automobile that led to the introduction of a local truck-moving service that forced his mule-and-cart business into obsolescence. Macon responded in song, quipping in "From Earth To Heaven," "I'd rather ride a wagon and go to heaven / Than to hell in an automobile" (Macon 2004).

It would be easy to dismiss such wit as that of a man and culture still stuck with one foot in the past century, and though that is partly the case, one should not ignore the knowingness of such humor. The exaggerated representations of backwards (and backwoods) hillbillies that populate the writings of Macon and other country artists signify self-consciousness as well as self-deprecation. As stated, no-one makes fun of rural America more than rural America itself. Whether it be Minnie Pearl sporting an absurd hat complete with hanging price tag, or Jeff Foxworthy drawling through a series of "You're a redneck if ..." gags, country humor - or "rube" humor - is grotesque humor. And its caricatures are self-created and aimed strictly for the in-crowd. Such insularity dramatizes country's differences from folk music expression, and reflects a concurrent anxious embarrassment and defensive pride, feelings likely to manifest in "Keep Out" signs rather than in calls for socio-political change.

\section{Jimmy Rodgers}

Country \& western's first national (as opposed to regional) success story, Jimmie Rodgers fused many of the influences of his time into an amalgam that would re-orient the genre onto a direct course towards rock \& roll. $\mathrm{He}$, more than anyone, transformed country from a parochial rural form into the more broad-reaching style it would become. In a six-year span between 1927 and 1933, Rodgers accumulated a body of work that would concretize the mythologies and methods of country music, and further its fundamental styles of fatalistic and tall-tale humor.

Born in Meridian, Mississippi, in 1897, Jimmie Rodgers' life appeared destined for hardship. His mother died when he was five and his father struggled as a foreman on the railroads. Young Jimmie learnt early the necessity of self-reliance, at thirteen joining a traveling medicine show. Periodically, he would work with his father on the railroads. These early teen years provided him with the themes that were to characterize his musical career: movement and suffering. And like the tall-tale humorists 
of past rural American writers, Rodgers brought an up-beat wit and vernacular grittiness to his narratives of brakemen, sailors, hobos, gamblers, cowboys, and rangers. Despite - or perhaps because of - the struggles of the Great Depression years during which he performed, Rodgers imbued these characters with a romanticist charm and spirit of escapist freedom. Their lives appeared to embody the liberationist possibilities that the economic conditions did not afford the working man. Rambling songs, the core of his repertoire, offered humor from hardship, inspiration and relief in the face of cold prospects. Often called "the singing brakeman," Rodgers, like Woody Guthrie, was an organic intellectual whose persona honestly reflected his material, even if that work was full of mythology and sentimental exaggerations. As other artists struggled to survive during the harsh early Depression years, Jimmie Rodgers' popularity soared; his patented yodels seemed to raise spirits and relieve woes wherever he would travel.

Besides his tales of freedom-seeking rogues and rebels, Jimmie Rodgers also revealed courage in his self-effacing wit. A staple of country humor, Rodgers would address his personal crises with a fatalistic resignation that wore a mask of lightheartedness. A life-long sufferer from tuberculosis, a disease he had genetically inherited from his mother, Rodgers wrote of his pain with a good humor that accentuated his resilient strength. In "Whippin' That Old T.B." and "T.B. Blues," Rodgers continued a blues tradition that had often addressed this killer disease during the 1920s and '30s. In the latter song, he mourned, "When it rained down sorrow it rained all over me / Cos my body rattles like a train on that old S.B. / I've got the T.B. blues" (Rodgers 1997). As these songs forecast, T.B. was to claim Rodgers' life - by the time he reached thirty-six years-ofage.

From his lighter side, Rodgers occasionally wrote in the vein of the sexually risqué lyrics so prominent in black blues culture, yet so uncommon in staunchly conservative, white rural communities and music. In "Pistol Packin' Papa" he tells one of his typical tall-tales of a rambler, but then includes the strangely suggestive verse: "Now girls I'm just a good guy and I'm going to have my fun / And if you don't want to smell my smoke don't monkey with my gun" (Rodgers 1997). Such bawdy lyricism saw Rodgers expanding the content range of country's humor, the parochial confines of white rural humor challenged simultaneously. George Lipsitz further notes the class dimension to Rodgers' "favorable reception" of blues characteristics, suggesting that it "represent[ed] an identification 
with another view of the world than the one promulgated by bourgeois culture" (1987: 299).

In skirting the boundaries of black and white musical forms, and expanding the breadth of country humor within and beyond rural communities, Jimmie Rodgers took the genre to new destinations, making him a significant forerunner of rock \& roll. His influence can be felt throughout country music history, particularly on the more irreverent edges where the likes of Kinky Friedman and Dwight Yoakam reside. Beyond country, too, his legacy lingers, such that today he is as revered within alternative rock circles as he is elsewhere.

\section{Hank Williams}

If Uncle Dave Macon was the grandfather of country music and Jimmie Rodgers was the father, then Alabama's King Hiram Williams was, as his Christian name suggests, its king. And if Rodgers radically shifted the course of the country \& western genre, Hank revolutionized it, making an internationalized American form from a regional, rural one. After the stripped-down, low-key sounds of the 1930s, Hank Williams brought jaunty honky-tonk rhythms to 1940 s country music, re-formulating the sound for its subsequent mutation into the rockabilly explosions of the mid-1950s.

As much as Hank Williams was a mover and shaker of country, he also embodied many of its traditional characteristics - particularly in relation to humor. Like his predecessors, Williams used wit as a way of looking at individual troubles and turmoil. As with Jimmie Rodgers, physical ailments plagued his life (in Hank's case chronic back pains), and suffering is a core theme in many of his songs. However, it is the power of Hank's transformative humor that keeps the songs from gratuitous self-pity, lending them a comforting relief and light-hearted sympathy. His MGM debut single, "Move It On Over" (1978), is emblematic of Hank's (and country's) humor. Employing unpretentious, everyday, homely imagery, the song treads into country's familiar territory of the battle of the sexes. Its loser humor has the narrator being cast out of the house by his wife for infidelity. "She told me not to play around / But I done let the deal go down," bemoans Hank, as he is then forced to share cramped living quarters with his dog in the outside kennel (Williams 1990). Articulated through the linguistic wit of working-class vernacular ("I done let"), 
"Move It On Over" contemplates the inevitable confinement that comes with family and stability. This call of the individual, unable to settle down, is further captured in the poetic lyrics of "Rambling Man," where the narrator confesses, "There's somethin' o'er that hill that I gotta see / If I didn't go I believe I'd blow my stack" (Williams 1990). Like Jimmie Rodgers' song-characters, these are men with children's spirits, unwilling (or unable) to be tied down to the hardships of adult responsibilities.

Williams' self-reflective humor cuts to the heart of his being, one torn between sin and salvation. It is the dichotomous paradox that resides within so much country humor, as well as in the personal-artistic struggles of predecessors like blues-man Robert Johnson and succeeding rockers like Elvis Presley and Jerry Lee Lewis. And as with Uncle Dave Macon and Jimmie Rodgers before him, Williams constantly shifted between the two poles, sometimes singing pure songs of gospel faith (usually under the pseudonym of Luke the Drifter), while other times laughing at his own sinning ways. It is in the latter songs where humor is employed to escape the religious guilt and indulge the adventurous heart. In "Why Don't You Love Me?" the faux-naive narrator wryly inquires, "I'm the same old trouble that you've always been through / So why don't you love me like you used to do?" (Williams 1990). And not only did trouble seem to follow Hank around, but he often chased it with the help of the bottle. It was drink that got him banned from the Grand Ole Opry, it was drink that exacerbated the tumult in his marriage to Audrey Sheppard, and it was drink that ultimately led to the heart attack that killed him before he reached the age of thirty. Yet, despite the misery his alcoholic life brought, Williams still humorously repressed (or defended) his sins behind such songs as "Mind Your Own Business" ("and you wont be minding mine") and "My Bucket's Got a Hole in It" (I can't buy no beer") (Williams 1990). Such candid, self-effacing wit of woes bore the stamp of working-class authenticity so crucial to country credibility, whilst Williams' domestic, banal topics reflected country's insular mindset and personalized concerns.

Besides his broad musical appeals, Hank Williams was also a legend of the honky-tonk stage. With his tall frame slouched over the microphone, he performed with a swagger and animal magnetism that had young men admiring his natural cool and young women swooning at his comic gyrations; such responses would foreshadow the similar cross-gender appeals and physical humor of Elvis Presley a decade later. Coupled with a vocal style and delivery that was emotionally penetrating and tongue-in-cheek, 
Williams provided his legions of fans with the blueprint of the workingclass rebel rocker that was to inform other young, white, Southern performers a few years hence. In death as in life, Hank Williams elicited reactions befitting a proto-rock star; his funeral in Montgomery drew almost three thousand mourners. With the king of country passing in 1953, the empty stage did not have to wait too long for the Deep South to provide a new king for a new generation of youth.

The international success of Hank Williams marked the end of country $\&$ western music as a distinctly regional and working-class expression. Country's subsequent popularization - and that of folk music - has had the positive effect of expanding the reach of the forms and their artists. However, the organic connectedness of artist and audience became increasingly fractured as these genres adopted the star system, gimmicks, and commercial imperatives of the incipient rock \& roll movement. George Lipsitz bemoans these developments, stating, "the music was not designed primarily to be bought and sold; it served social purposes" (Lipsitz 1987: 294). As folk and country music became subsumed into rock contexts, they undoubtedly lost some of their previous raw realism and rural, working-class roots, though their foundational tenets and subversive humor are still recognizable through certain artists today. The resistant satire of folk is still alive and active in the hands of modern folkies like Billy Bragg and Steve Earle, while the self-effacing relief humor of country continues to flourish via such alt-country "rubes" as the Meat Purveyors, Splitlip Rayfield, and Truckstop Honeymoon.

University of Kansas

\section{Note}

Correspondence address: ellisiain@hotmail.com

\section{References}

Guthrie, Woody. 1999. Pretty Boy Floyd. The Asch recordings, Vol. 1-4. Smithsonian Folkways.

Guthrie, Woody. 2000. Dust pneumonia blues. Dust Bowl ballads. Buddha.

Hill, Joe. 1992. Don't mourn — organize! Songs of labor songwriter Joe Hill (Various Artists). Smithsonian Folkways. 
Lipsitz, George. 1987. Working people's music. In Donald Lazere (ed.), American media and mass culture: Left perspectives, 293-308. Berkeley: University of California Press.

Macon, Uncle Dave. 2004. Keep my skillet good and greasy: The complete recordings $(9 \mathrm{CD} /$ 1 DVD BOX with 176-page book). Bear Family.

Malone, Bill. 2001. Don't get above your raisin': Country music and the Southern working class. Champaign: University of Illinois Press.

Malone, Bill. 2002. Country music, U.S.A. Austin: University of Texas Press.

Morreall, John. 1983. Taking laughter seriously. Albany: State University of New York Press.

Pratt, Ray. 1990. Rhythm and resistance: Explorations in the political uses of popular music. New York: Praeger.

Rodgers, Jimmy. 1997. The essential Jimmie Rodgers. RCA.

Seeger, Pete. 1972. The incompleat folksinger. New York: Simon \& Schuster.

Williams, Hank. 1990. 40 greatest hits. Polygram Records. 
Copyright of Humor: International Journal of Humor Research is the property of De Gruyter and its content may not be copied or emailed to multiple sites or posted to a listserv without the copyright holder's express written permission. However, users may print, download, or email articles for individual use. 